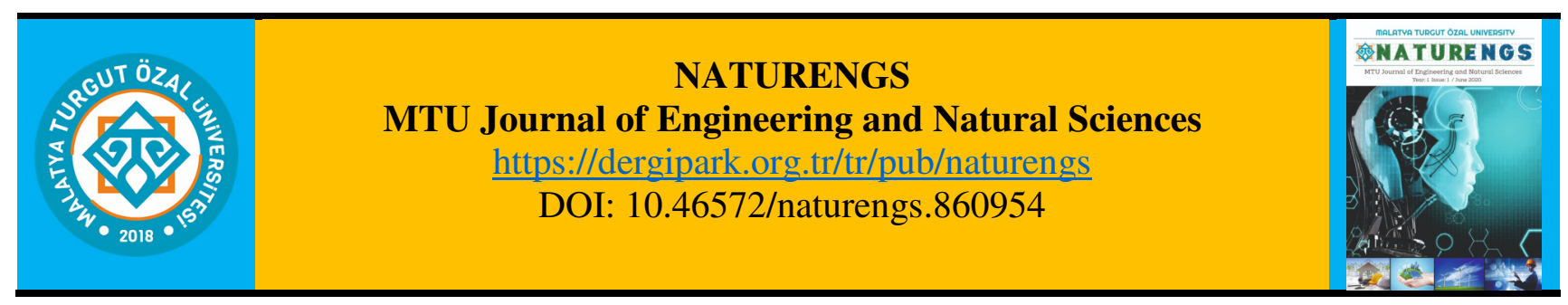

Research Article

\title{
Attitudes Towards Vaccines And Intention to Vaccinate Against Covid-19: A Statistical Analysis
}

\author{
Burcu Özcan ${ }^{1}$, Edanur Yıldırak ${ }^{2}$, Zeynep Aksoy ${ }^{3 *}$ \\ 1,2,3 Industrial Engineering, Faculty of Engineering, Kocaeli University, Kocaeli, Turkey.
}

(Received: 15.01.2021; Accepted: 09.05.2021)

\begin{abstract}
Present study aims to analyze the attitude towards Covid 19 vaccine in Kocaeli province and the factors that may cause this attitude. Data were applied to 248 people via an online survey. The survey consists of three parts: demographic data, data on vaccine attitude and level of knowledge about the vaccine. The association between the idea of being vaccinated and demographic variables were examined with Pearson chi-square analysis and a significant relationship was found only in terms of age and marital status variables. Pearson's correlation analysis was used to determine the relationship between the vaccine attitude scores and the level of knowledge about the vaccine. It was concluded that the relationship between age and marital status with the idea of vaccination was statistically significant. $(\mathrm{P}<0,01) \mathrm{T}$-test was used to determine whether it differentiated according to chronic illness and it was determined that it did not. ( $>>0,05)$ One-way ANOVA was used for the relationship between fear level against Covid 19 and attitude towards a vaccine and it was observed that there was a significant difference. The effect of seeing social media and television as a source of information on the idea of vaccination was examined using Ordinal Logistics Regression according to the determined reference values and it was seen that there was a significant difference. Also, domestic vaccine positively affects the attitude towards a vaccine.
\end{abstract}

Keywords: Covid 19, Vaccine attitude, Vaccination misinformation, Statistical analyze.

\section{INTRODUCTION}

The main purpose of health services is to ensure the continuity of health. Vaccination is one of the most important methods to protect against diseases.

According to the statement made by the Ministry of Health in December 2017, the number of families who refused vaccination exceeded 10,000.

It is very important to examine the fears and concerns of individuals against the vaccine and the factors that may cause this situation and to create a vaccine policy in this direction. Providing accurate information about the vaccine has become an important issue in this process. Otherwise, there will be an increase in epidemic diseases. When the literature is examined, the reasons for not being vaccinated are fear and insecurity against the side effects of vaccines that may occur soon or in the long term. In December 2019, China announced the first cases of coronavirus Disease (COVID-19) due to a new Coronavirus: Severe Acute Respiratory Syndrome-Coronavirus 2 (SARS-CoV 2). The world is currently fighting a serious pandemic, 
with more than 61 million people infected with this virus worldwide, cases have been reported from more than 200 countries, and more than 1.43 million people have died by the date of this study [1]. Vaccination is the only viable way to keep this pandemic under control.

In the current covid-19 pandemic, the public's attitude to the vaccine, which is uncertain, is critical for mass immunity. For this reason, in this study, the attitudes and reasons of people living in different occupational groups and regions in Kocaeli, which is among the top five provinces in the country with a high number of cases, will be examined. In the study, a questionnaire including demographic, socio-economic variables, examining the reasons for not being vaccinated, and measuring virus and vaccine information was applied to the participants. The significance of the obtained data and the relationships of independent variables with vaccine attitude will be examined in the findings section.

The literature research conducted is summarized in Table 1, Table 2, Table 3, Table 4 and Table 5.

Table 1. Literature Research Table Summary 1

\begin{tabular}{|c|c|c|c|c|c|}
\hline YEAR & PURPOSE & AUTHOR & $\begin{array}{c}\text { INDEPENDENT } \\
\text { VARIABLES } \\
\end{array}$ & $\begin{array}{c}\text { TEST } \\
\text { STATISTICS } \\
\end{array}$ & $\begin{array}{l}\text { SAMPLE } \\
\text { SIZE }\end{array}$ \\
\hline 2007 & $\begin{array}{l}\text { Parents' attitude } \\
\text { towards vaccines }\end{array}$ & Benford, Lansley [2] & $\begin{array}{c}\text { Economic } \\
\text { situation, } \\
\text { Ethnicity }\end{array}$ & $\begin{array}{l}\text { One Way } \\
\text { ANOVA }\end{array}$ & 2326 \\
\hline 2011 & $\begin{array}{l}\text { Attitudes of people } \\
\text { living in Hungary } \\
\text { towards HPV vaccine }\end{array}$ & Marek et al. [3] & $\begin{array}{l}\text { Age, gender, } \\
\text { region, cost } \\
\text { attitude to the } \\
\text { HPV vaccine, } \\
\text { health information } \\
\text { of the participants }\end{array}$ & $\begin{array}{l}\text { Pearson Chi } \\
\text { Square Test }\end{array}$ & 298 \\
\hline 2012 & $\begin{array}{l}\text { Attitudes of dentists } \\
\text { living in Germany } \\
\text { towards seasonal flu } \\
\text { vaccine and pandemic } \\
\text { flu vaccine }\end{array}$ & Wicker et al. [4] & $\begin{array}{l}\text { Age, gender, } \\
\text { acceptance of } \\
\text { H1N1 vaccine at } \\
\text { the time of } 2010- \\
\quad 2011\end{array}$ & $\begin{array}{l}\text { Pearson Chi } \\
\text { Square }\end{array}$ & 242 \\
\hline 2015 & $\begin{array}{c}\text { Attitudes of female } \\
\text { students in a school in } \\
\text { Lebanon towards HPV } \\
\text { vaccine }\end{array}$ & Danny et al. [5] & $\begin{array}{c}\text { Demographic } \\
\text { information such } \\
\text { as smoking, age, } \\
\text { sexual experience, } \\
\text { education }\end{array}$ & $\begin{array}{c}\text { ANOVA, Paired T } \\
\text { Test, }\end{array}$ & 512 \\
\hline 2016 & $\begin{array}{l}\text { In a study conducted in } \\
67 \text { countries, the } \\
\text { relationship between } \\
\text { religion and vaccine } \\
\text { attitude was examined. }\end{array}$ & Larson et al. [6] & $\begin{array}{l}\text { Economic } \\
\text { situation, } \\
\text { geographical } \\
\text { location }\end{array}$ & $\begin{array}{c}\text { Regression } \\
\text { Analysis, } \mathrm{T} \text { test }\end{array}$ & 65.819 \\
\hline 2016 & $\begin{array}{l}\text { The impact of policy } \\
\text { changes on the flu } \\
\text { vaccine }\end{array}$ & Slaun white [7] & $\begin{array}{l}\text { The social and } \\
\text { economic status of } \\
\text { the person }\end{array}$ & T Ttest & 202 \\
\hline 2017 & $\begin{array}{l}\text { The attitudes of elderly } \\
\text { people living in } \\
\text { Singapore towards flu } \\
\text { and pneumonia } \\
\text { vaccine have been } \\
\text { examined }\end{array}$ & Chow et al. [8] & $\begin{array}{l}\text { Age, gender, } \\
\text { chronic illnesses, } \\
\text { type of housing, } \\
\text { income status, } \\
\text { ethnicity }\end{array}$ & $\begin{array}{c}\text { T Test, Wilcoxon } \\
\text { Test, McNemar } \\
\text { Test, Ordinal } \\
\text { Logistic } \\
\text { Regression }\end{array}$ & 655 \\
\hline
\end{tabular}


Table 2. Literature Research Table Summary 2

\begin{tabular}{|c|c|c|c|c|c|}
\hline YEAR & PURPOSE & AUTHOR & $\begin{array}{l}\text { INDEPENDENT } \\
\text { VARIABLES }\end{array}$ & $\begin{array}{c}\text { TEST } \\
\text { STATISTIC } \\
\mathbf{S}\end{array}$ & $\begin{array}{l}\text { SAMPLE } \\
\text { SIZE }\end{array}$ \\
\hline 2017 & $\begin{array}{c}\text { Flu vaccine against the } \\
\text { attitude of the parents } \\
\text { of allergic rhinitis and } \\
\text { asthma patients and } \\
\text { doctors living in } \\
\text { Turkey }\end{array}$ & Kaya et al. [9] & $\begin{array}{l}\text { Demographic and } \\
\text { health variables }\end{array}$ & $\begin{array}{l}\text { Pearson Chi } \\
\text { Square Test }\end{array}$ & $189-183$ \\
\hline 2017 & $\begin{array}{l}\text { Public attitude towards } \\
\text { childhood vaccinations } \\
\text { in New Zealand }\end{array}$ & Lee et al. [10] & $\begin{array}{l}\text { Gender, marital } \\
\text { status, } \\
\text { employment } \\
\text { status, age, } \\
\text { number of } \\
\text { children and } \\
\text { annual household } \\
\text { income }\end{array}$ & $\begin{array}{c}\text { Multiple } \\
\text { Regression } \\
\text { Analysis }\end{array}$ & 16.642 \\
\hline 2017 & $\begin{array}{c}\text { Influence of race } \\
\text { against vaccination } \\
\text { attitude }\end{array}$ & Quinin et al. [11] & $\begin{array}{l}\text { Economic } \\
\text { situation, age }\end{array}$ & T Test & 1657 \\
\hline 2018 & $\begin{array}{c}\text { Healthcare } \\
\text { professionals' } \\
\text { hesitation about } \\
\text { vaccination }\end{array}$ & Succi [12] & $\begin{array}{c}\text { Geographical } \\
\text { location, ethnicity }\end{array}$ & $\begin{array}{c}\text { Regression } \\
\text { Analysis }\end{array}$ & 168 \\
\hline 2018 & $\begin{array}{c}\text { Attitude to hepatitis B } \\
\text { vaccine }\end{array}$ & Liu [13] & $\begin{array}{l}\text { Hospital policy, } \\
\text { size }\end{array}$ & ANOVA & 929 \\
\hline 2019 & $\begin{array}{c}\text { The effect of } \\
\text { superstitions on } \\
\text { attitude to the flu } \\
\text { vaccine }\end{array}$ & Lu et al. [14] & $\begin{array}{l}\text { Education level, } \\
\text { Economic status }\end{array}$ & $\begin{array}{l}\text { Pearson Chi } \\
\text { Square Test }\end{array}$ & 668 \\
\hline
\end{tabular}


Table 3. Literature Research Table Summary 3

\begin{tabular}{|c|c|c|c|c|c|}
\hline YEAR & PURPOSE & AUTHOR & $\begin{array}{l}\text { INDEPENDENT } \\
\text { VARIABLES }\end{array}$ & $\begin{array}{c}\text { TEST } \\
\text { STATISTICS }\end{array}$ & $\begin{array}{l}\text { SAMPLE } \\
\text { SIZE }\end{array}$ \\
\hline 2019 & $\begin{array}{l}\text { Ebola vaccine acceptability } \\
\text { in West Africa }\end{array}$ & $\begin{array}{c}\text { Jalloh et al. } \\
{[15]}\end{array}$ & Social status, Age, Education & $\begin{array}{l}\text { Qualitative and } \\
\text { quantitative } \\
\text { analysis }\end{array}$ & 316 \\
\hline 2019 & $\begin{array}{c}\text { Attitude towards HPV } \\
\text { vaccine in India }\end{array}$ & $\begin{array}{l}\text { Dagarege et } \\
\text { al. [16] }\end{array}$ & $\begin{array}{l}\text { Religion, social factors, } \\
\text { education }\end{array}$ & $\begin{array}{c}\text { Regression } \\
\text { Analysis }\end{array}$ & 1609 \\
\hline 2020 & $\begin{array}{c}\text { Australian residents' } \\
\text { attitude towards mumps, } \\
\text { measles and rubella } \\
\text { vaccines }\end{array}$ & $\begin{array}{c}\text { Toll et al. } \\
\text { [17] }\end{array}$ & $\begin{array}{l}\text { Demographic, } \\
\text { socioeconomic and health- } \\
\text { related variables }\end{array}$ & $\begin{array}{c}\text { Multiple } \\
\text { Regression } \\
\text { Analysis }\end{array}$ & 4779 \\
\hline 2020 & $\begin{array}{c}\text { The attitude of pregnant } \\
\text { women towards flu vaccine } \\
\text { in Kenya }\end{array}$ & $\begin{array}{c}\text { Otieno et al. } \\
\text { [18] }\end{array}$ & $\begin{array}{l}\text { Education level, age, marital } \\
\text { status, income status, } \\
\text { religion, region of residence, } \\
\text { number of children }\end{array}$ & $\begin{array}{l}\text { Fisher Chi } \\
\text { Square Test }\end{array}$ & 507 \\
\hline 2020 & $\begin{array}{l}\text { The attitudes of pregnant } \\
\text { women towards pediatric } \\
\text { vaccination in Greece }\end{array}$ & $\begin{array}{l}\text { Maltezou et } \\
\text { al. [19] }\end{array}$ & $\begin{array}{c}\text { Age, gestational age, } \\
\text { education level, current } \\
\text { childbearing, prior flu } \\
\text { vaccination and vaccination } \\
\text { beliefs of women }\end{array}$ & $\begin{array}{c}\text { Logistics } \\
\text { Regression }\end{array}$ & 814 \\
\hline 2020 & $\begin{array}{l}\text { Flu vaccine knowledge and } \\
\text { attitude of parents of } \\
\text { children hospitalized for flu } \\
\text { in Australia }\end{array}$ & $\begin{array}{l}\text { Carlson et al. } \\
{[20]}\end{array}$ & $\begin{array}{l}\text { Child's age, length of stay } \\
\text { hospital, by region of } \\
\text { residence, gender, pregnancy } \\
\text { vaccination }\end{array}$ & ANOVA & 27 \\
\hline
\end{tabular}


Table 4. Literature Research Table Summary 4

\begin{tabular}{|c|c|c|c|c|c|}
\hline YEAR & PURPOSE & AUTHOR & $\begin{array}{l}\text { INDEPENDENT } \\
\text { VARIABLES }\end{array}$ & $\begin{array}{c}\text { TEST } \\
\text { STATISTICS }\end{array}$ & $\begin{array}{l}\text { SAMPLE } \\
\text { SIZE }\end{array}$ \\
\hline 2020 & $\begin{array}{l}\text { Flu vaccine attitudes of } \\
\text { teachers living in Poland. }\end{array}$ & Ganczak [21] & $\begin{array}{l}\text { Gender, residence (city, } \\
\text { rural), marital status, } \\
\text { socioeconomic status, } \\
\text { belief that they will be in } \\
\text { the high risk group for } \\
\text { influenza }\end{array}$ & $\begin{array}{c}\text { Fisher Chi Square } \\
\text { Test }\end{array}$ & 277 \\
\hline 2020 & $\begin{array}{l}\text { The role of the digital } \\
\text { platform in vaccination }\end{array}$ & $\begin{array}{l}\text { Franscella et } \\
\text { al. [22] }\end{array}$ & $\begin{array}{l}\text { Age, economic situation, } \\
\text { religion }\end{array}$ & ANOVA & 919 \\
\hline 2020 & $\begin{array}{l}\text { The effect of doctors on } \\
\text { patients who do not want to } \\
\text { be vaccinated }\end{array}$ & $\begin{array}{l}\text { Deml et al. } \\
\text { [23] }\end{array}$ & $\begin{array}{l}\text { The social life of the } \\
\text { person, Education }\end{array}$ & $\begin{array}{c}\text { Regression } \\
\text { Analysis }\end{array}$ & 20 \\
\hline 2020 & $\begin{array}{l}\text { Access and acceptance of } \\
\text { the vaccine }\end{array}$ & Spana [24] & $\begin{array}{l}\text { Social and behavioral } \\
\text { communication, Human } \\
\text { factors }\end{array}$ & $\begin{array}{c}\text { Experimental } \\
\text { Suggestion } \\
\text { Provided }\end{array}$ & 23 \\
\hline 2020 & $\begin{array}{c}\text { Whether HPV is applied by } \\
\text { human rights or not }\end{array}$ & $\begin{array}{c}\text { Kruese et al. } \\
{[25]}\end{array}$ & Age, gender & $\begin{array}{c}\text { Statistical Data } \\
\text { Analysis }\end{array}$ & 154 \\
\hline 2020 & $\begin{array}{l}\text { Vaccination attitudes have } \\
\text { been examined on social } \\
\text { media }\end{array}$ & $\begin{array}{l}\text { Chan et al. } \\
\text { [26] }\end{array}$ & Social features, Age & $\begin{array}{c}\text { Correlation } \\
\text { Analysis }\end{array}$ & 3005 \\
\hline
\end{tabular}


Table 5. Literature Research Table Summary 5

\begin{tabular}{|c|c|c|c|c|c|}
\hline YEAR & PURPOSE & AUTHOR & $\begin{array}{l}\text { INDEPENDENT } \\
\text { VARIABLES }\end{array}$ & $\begin{array}{c}\text { TEST } \\
\text { STATISTICS }\end{array}$ & $\begin{array}{l}\text { SAMPL } \\
\text { E SIZE }\end{array}$ \\
\hline 2020 & $\begin{array}{l}\text { Cancer patients' attitudes } \\
\text { towards flu vaccine }\end{array}$ & $\begin{array}{l}\text { Okoli et al. } \\
\text { [27] }\end{array}$ & $\begin{array}{l}\text { Age, education, gender, } \\
\text { smoking, income, residency } \\
\text { insurance, cancer type, } \\
\text { chronic disease, year of } \\
\text { diagnosis, occupation }\end{array}$ & $I^{2}$ test & $\begin{array}{c}139- \\
41.346\end{array}$ \\
\hline 2020 & $\begin{array}{c}\text { Parents' attitude towards } \\
\text { childhood vaccinations in } \\
\text { New Zealand }\end{array}$ & $\begin{array}{l}\text { Lee et al. } \\
\text { [28] }\end{array}$ & $\begin{array}{l}\text { Age, race, region and } \\
\text { educational status }\end{array}$ & $\begin{array}{c}\text { Actor-Partner } \\
\text { Mutual Dependency } \\
\text { Model }\end{array}$ & 136 \\
\hline 2020 & $\begin{array}{l}\text { Flu vaccine and covid-19 } \\
\text { vaccine attitude of } \\
\text { healthcare professionals } \\
\text { living in Malta }\end{array}$ & Grech [29] & $\begin{array}{l}\text { Age, gender, health status, } \\
\text { vaccine concern, effect, } \\
\text { safety }\end{array}$ & $\begin{array}{c}\text { Fisher Chi Square } \\
\text { Test }\end{array}$ & 852 \\
\hline 2020 & $\begin{array}{c}\text { Parents' attitude towards } \\
\text { covid-19 vaccine in a study } \\
\text { conducted in the UK }\end{array}$ & $\begin{array}{l}\text { Bell et al. } \\
{[30]}\end{array}$ & $\begin{array}{c}\text { Age, gender, household } \\
\text { income, employment, marital } \\
\text { status of participants, and } \\
\text { number and age of children }\end{array}$ & Paired T Test & 1252 \\
\hline 2020 & $\begin{array}{l}\text { Vaccination status of } \\
\text { children with IBH and } \\
\text { AIH living in Germany }\end{array}$ & $\begin{array}{c}\text { Cagol et al. } \\
\text { [31] }\end{array}$ & $\begin{array}{c}\text { Gender, current age, age at } \\
\text { diagnosis, treatment and } \\
\text { disease }\end{array}$ & $\begin{array}{l}\text { ANOVA, Kruskal } \\
\text { Wallis, Wilcoxon, } \\
\text { Fisher Chi Square } \\
\text { Test }\end{array}$ & 329 \\
\hline 2020 & $\begin{array}{l}\text { The relationship of the } \\
\text { public's political opinion } \\
\text { with the attitude to the } \\
\text { covid-19 vaccine in France }\end{array}$ & $\begin{array}{l}\text { Ward et al. } \\
\text { [32] }\end{array}$ & $\begin{array}{c}\text { Gender, age, education, } \\
\text { income, Covid } 19 \text { diagnosis, } \\
\text { political }\end{array}$ & Logistic Regression & 5018 \\
\hline 2020 & $\begin{array}{l}\text { Caregivers' attitude } \\
\text { towards vaccination }\end{array}$ & $\begin{array}{l}\text { Goldman et } \\
\text { al. [33] }\end{array}$ & $\begin{array}{l}\text { Cultural environment, } \\
\text { geographic location }\end{array}$ & $\begin{array}{c}\text { Pearson Chi Square } \\
\text { Test }\end{array}$ & 2557 \\
\hline
\end{tabular}

In the study, the attitude of individuals living in Kocaeli province towards the COVID 19 vaccine was examined. The problems to be investigated in the study can be listed as follows. 1. Whether there is a relationship between demographic variables and vaccination idea 2. The relationship between seeing social media and television as a means of obtaining information and the idea of getting vaccinated

3.The effect of the domestic vaccine on attitude

4. Effect of total knowledge score on attitude towards vaccine

5. The relationship between vaccination attitude and education level

6 . The relationship between the fear level and the vaccine attitude score

7. Determining the relationship between chronic illness and desire to be vaccinated 


\section{MATERIAL AND METHODS}

\subsection{Sample Group}

In the study, Kocaeli, which is at the top of the number of cases during the pandemic period, was selected as the population. Self-administered online questionnaire questions were asked to 248 participants in multiple districts, different income levels and professions. Participation in the survey took place between 30 November and 3 December. The descriptive statistics of the demographic characteristics of the participants are shown in Table 6.

Table 6. The descriptive statistics of the demographic characteristics of the participants

\begin{tabular}{|c|c|c|}
\hline Gender & Frequency & $\begin{array}{l}\text { Percent } \\
\text { Frequency }\end{array}$ \\
\hline Woman & 133 & 53.6 \\
\hline Male & 115 & 46.4 \\
\hline Total & 248 & 100 \\
\hline Marital status & Frequency & $\begin{array}{l}\text { Percent } \\
\text { Frequency }\end{array}$ \\
\hline The married & 144 & 58.1 \\
\hline Single & 104 & 41.9 \\
\hline Total & 248 & 100 \\
\hline Education Status & Frequency & $\begin{array}{l}\text { Percent } \\
\text { Frequency }\end{array}$ \\
\hline $\begin{array}{l}\text { Primary School- } \\
\text { Secondary School }\end{array}$ & 78 & 31.5 \\
\hline High school & 60 & 24.2 \\
\hline University & 89 & 35.9 \\
\hline Postgraduate & 21 & 8.5 \\
\hline Total & 248 & 100 \\
\hline Age & Frequency & $\begin{array}{l}\text { Percent } \\
\text { Frequency }\end{array}$ \\
\hline 18-28 Age & 82 & 33.2 \\
\hline 29-39 Age & 33 & 13.4 \\
\hline 40-50 Age & 21 & 8.5 \\
\hline 50-60 Age & 37 & 15.0 \\
\hline $60+$ & 74 & 30.0 \\
\hline Total & 247 & 100 \\
\hline
\end{tabular}

\subsection{Data Collection Tool and Method}

In the study, the data was provided through a questionnaire that can be answered online. In the questionnaire answered by 248 participants, demographic questions such as age, gender, marital status, educational status, information obtained (TV, social media, experts, scientific 
publications), presence of chronic illness consisting of yes-no answers, previous disease status, vaccination training (1-Strongly disagree, 2-Disagree, 3-Indecisive, 4-Agree, 5-Strongly Agree), questions such as income loss status, confidence of the participant against the vaccine, belief in its protection, idea of vaccination, information about the vaccine the effect of vaccine trust on the vaccine trust, the effect of the vaccine on the vaccine trust, the effect of the vaccine's institution on the vaccine attitude, the effect of the vaccination fee on the vaccination decision, the effect of the expert advice on the vaccination attitude, the effect of the vaccine's success rate on the vaccination decision, the effect of the vaccine storage conditions on the vaccination decision There are questions measuring fear, and true-false questions to measure vaccine knowledge.

Pearson chi-square analysis was conducted to examine the relationship between demographic variables and vaccination attitude, which we determined as the dependent variable. First, the hypothesis test is established, the established hypothesis is shown.

\subsection{Analysis of Data on Attitude Against Vaccine}

To analyze the sample group, the reliability of the data was tested first. (Tabachnick \& Fidell, 2013), the skewness and kurtosis values between -1.5 and +1.5 show that they are normally distributed. A normality test was performed and kurtosis and skewness values were found to be between these values for 22 different variables, and normal distribution was appropriate. According to Özdamar (2015), Cronbach's Alpha value is between 0.70 and 0.90 shows that the scale has high reliability, it takes a value between 0.60 and 0.70 , and the scale has sufficient reliability. 22 different factors of vaccination attitude, Cronbach alpha value. It was found to be 0.830 .

\section{RESULTS AND DISCUSSION}

\subsection{Chi-Square Analysis of the Relationship Between Demographic Variables and Vaccination Idea}

Pearson chi-square analysis was conducted to examine the relationship between demographic variables and vaccination attitude, which we determined as the dependent variable. First, the hypothesis test is established, the established hypothesis is shown.

Table 7. Age-Vaccination Thought Observed and Expected Value

\begin{tabular}{|c|c|c|c|c|c|c|c|c|c|}
\hline \multirow{3}{*}{\multicolumn{2}{|c|}{ Age }} & \multicolumn{6}{|c|}{ Vaccination Thought } & \multirow{3}{*}{ Total } & \multirow{3}{*}{ Sig. } \\
\hline & & \multicolumn{2}{|c|}{ I don't think } & \multicolumn{2}{|c|}{ I am intensive } & \multicolumn{2}{|c|}{ I think } & & \\
\hline & & $\mathbf{N}$ & $\begin{array}{l}\text { Post- } \\
\text { Hoc }\end{array}$ & $\mathbf{N}$ & $\begin{array}{l}\text { Post- } \\
\text { Hoc }\end{array}$ & $\mathbf{N}$ & $\begin{array}{l}\text { Post- } \\
\text { Hoc }\end{array}$ & & \\
\hline 18-40 Age & Count & 42 & $42 \mathrm{a}$ & 41 & $41 \mathrm{a}$ & 32 & $32 \mathrm{a}$ & 115 & \\
\hline $40+$ Age & Count & 15 & $15 \mathrm{~b}$ & 38 & $38 \mathrm{a}$ & 79 & $79 \mathrm{~b}$ & 132 & \\
\hline \multicolumn{2}{|l|}{ Total } & 57 & & 79 & & 111 & & 247 & 0.000 \\
\hline
\end{tabular}

The age independent variable is evaluated in terms of vaccination attitude. To prevent $20 \%$ of the data being under five, the age variable considered in five groups (18-28, 29-39, 40-50, 50- 
$60,60+)$ is combined into two groups. Likewise, the idea of vaccination stated in the 5-point Likert scale is combined into three evaluations. As can be seen in Table 7, it is seen that the participants in the 18-40 age group mostly answered "I do not think", and the participants over the age of 40 answered "I think" more.

Looking at the Pearson chi-square result, it is seen that the $\mathrm{p}$ value is less than 0.05 . Therefore, $\mathrm{H}_{0}$ is rejected. It is commented that there is a statistically significant relationship between age and the idea of being vaccinated.

A comparison of the columns is made. In Table 7, it is seen that there is a significant difference between the columns expressed with different letters. It is seen that there is a difference between the ages of 18-40 and over 40 in terms of thinking about vaccination, and there is no difference between the two age groups in terms of indecision towards vaccination.

Table 8. Expected and Observed Values of the Vaccination Thought by Gender

\begin{tabular}{|c|c|c|c|c|c|c|}
\hline \multirow{2}{*}{\multicolumn{2}{|c|}{ Gender }} & \multicolumn{3}{|c|}{\begin{tabular}{|l|} 
Vaccine Thought \\
\end{tabular}} & \multirow[b]{2}{*}{ Total } & \multirow[b]{2}{*}{ Sig } \\
\hline & & I don't think & I am indecisive & I think & & \\
\hline Female & Count & 34 & 41 & 58 & 133 & \multirow{3}{*}{0.583} \\
\hline Male & Count & 23 & 38 & 54 & 115 & \\
\hline Total & & 57 & 79 & 112 & 248 & \\
\hline
\end{tabular}

Considering the idea of getting vaccinated according to the gender independent variable, it is seen that female participants responded with "I think" more, and male participants responded more "I think".

Table 9. Expected and Observed Values of Vaccination Thought According to Education

\begin{tabular}{|c|c|c|c|c|c|c|}
\hline \multirow{2}{*}{\multicolumn{2}{|c|}{ Education }} & \multicolumn{3}{|c|}{ Vaccination Thought } & \multirow[b]{2}{*}{ Total } & \multirow[b]{2}{*}{ Sig. } \\
\hline & & I don't think & I am indecisive & I think & & \\
\hline $\begin{array}{l}\text { Primary/ } \\
\text { Secondary } \\
\text { School }\end{array}$ & Count & 14 & 22 & 42 & 78 & \multirow{4}{*}{0.151} \\
\hline High School & Count & 12 & 18 & 30 & 60 & \\
\hline University & Count & 31 & 39 & 40 & 110 & \\
\hline Total & & 57 & 79 & 112 & 248 & \\
\hline
\end{tabular}

When the idea of vaccination is evaluated according to the education independent variable, to prevent $20 \%$ of the expected value falling below 5 in four groups (primary school, secondary school, high school, university (associate degree, undergraduate), graduate (master, doctorate) The graduate group was merged with the university. As can be seen from the table, primarysecondary school graduates responded more "I think." Participants who were high school graduates and university graduates responded more like "I think". 
Considering the result of the Pearson chi-square analysis, it can be said that there is no significant relationship between the educational status variable and the idea of being vaccinated because the $\mathrm{p}$ value is above 0.05 and the $H_{0}$ a hypothesis is accepted.

Table 10. Pearson's Chi-Square Analysis Result of the Vaccination Thought According to Marital Status

\begin{tabular}{|l|l|l|l|l|l|l|}
\cline { 2 - 6 } \multicolumn{2}{c|}{} & \multicolumn{2}{l|}{ Vaccination Thought } & & \\
\hline \multicolumn{2}{|l|}{ Marital Status } & I don't think & I am indecisive & I think & Total & Sig. \\
\hline Married & Count & 23 & 37 & 84 & 144 & \\
\hline Single & Count & 34 & 42 & 28 & 104 & \multirow{2}{*}{0.000} \\
\hline Total & 57 & 79 & 112 & 248 & \\
\hline
\end{tabular}

When the marital status independent variable and the idea of being vaccinated are evaluated together, it is seen that married participants responded more like "I think" and single participants responded more "I think".

Pearson's chi-square analysis result is examined. It can be said that the $\mathrm{p}$ value is less than 0.05 , that is, the $H_{0}$ the hypothesis will be rejected, and there is a significant relationship between marital status and the idea of being vaccinated.

\subsection{Examining the Relationship Between Gender and Knowledge Level with $T$ Test}

The sub-problems of the study were examined and whether the data obtained from two independent variables were meaningful with each other or not.T test was applied and the confidence interval was stated as $95 \%$. It has been investigated whether gender is related to the level of knowledge of Covid 19. A total scoring was made in the information about the information.

Table 11. T Test Result for the Relationship Between Gender and Knowledge Level

\begin{tabular}{|l|l|l|l|l|}
\hline Gender & $\mathbf{N}$ & $\mathbf{X}$ & SS & Sig. \\
\hline Female & 133 & 0.819 & 0.184 & \\
\cline { 1 - 4 } Male & 115 & 0.787 & 0.214 & $0.207^{*}$ \\
\hline *p $<0.05$
\end{tabular}

There was no significant relationship between gender and level of knowledge.

\subsection{Examination of the Relationship Between Chronic Disease and Thinking of Being a Covid Vaccine Using T Test}

It has been investigated whether those with chronic diseases are related to the desire to get the Covid 19 vaccine.

Table 12. The T-Test Result of the Relationship Between Chronic Disease and Thinking About Covid Vaccine

\begin{tabular}{|l|l|l|l|l|}
\hline $\begin{array}{l}\text { Chronic } \\
\text { Disease }\end{array}$ & N & $\mathbf{X}$ & SS & P value \\
\hline Yes there is & 147 & 3.490 & 1.631 & \multirow{2}{*}{$0.578^{*}$} \\
\hline No not & 101 & 3.376 & 1.541 & \\
\hline
\end{tabular}

$$
* \mathrm{p}<0.05
$$


People with chronic diseases are more likely to be vaccinated than those who do not. However, there is no significant relationship between considering vaccination and chronic illness. People with chronic illnesses are expected to have a much higher request for vaccination than those who do not it may be thought to do.

\subsection{The Relationship Between Fear Level and Attitude Score Against Vaccine}

While the $\mathrm{H}_{0}$ hypothesis argues that there is no difference between the fear level and the idea of being vaccinated, the $\mathrm{H}_{1}$ hypothesis shows that there is a difference between them.

It is seen that there is a significant difference between the fear level of individuals and their attitude towards vaccination. To determine the direction of the difference, Turkey Test was conducted and it was observed that all groups differed significantly over each other. The vast majority of participants are extremely afraid of Covid 19.

Table 13. Result of the Relationship Between Fear Level and Attitude Score Against Vaccine

\begin{tabular}{|c|l|l|l|l|l|l|l|}
\hline & Fear-Level & N & X & SS & F & P Value & $\begin{array}{l}\text { Significant } \\
\text { Difference }\end{array}$ \\
\hline \multirow{4}{*}{$\begin{array}{c}\text { Attitude } \\
\text { Score }\end{array}$} & I have no fear & 32 & 2.819 & 0.884 & & \multirow{2}{*}{25.799} & 0.0006 \\
\cline { 2 - 5 } & $\begin{array}{l}\text { Moderately } \\
\text { scared }\end{array}$ & 62 & 3.411 & 0.607 & $\begin{array}{l}\text { I have no } \\
\text { fear- } \\
\text { Moderate-I } \\
\text { am extremely } \\
\text { afraid }\end{array}$ \\
\cline { 2 - 5 } & I'm too afraid & 154 & 3.764 & 0.693 & & & \\
\hline
\end{tabular}

\subsection{The Relationship Between Vaccine Domestic Status and WHO Support and Attitude Score Against Vaccine}

There is a significant relationship between the vaccine being indigenous and being supported by WHO and the attitude towards the vaccine.

Table 14. Result of the Relationship Between Local Vaccine and WHO Support and Attitude Score Against Vaccine

\begin{tabular}{|c|c|c|c|c|c|c|c|}
\hline & $\begin{array}{l}\text { Local Vaccine- } \\
\text { WHO Support }\end{array}$ & $\mathbf{N}$ & $\mathbf{X}$ & SS & $\mathbf{F}$ & P Value & $\begin{array}{l}\text { Significant } \\
\text { Difference }\end{array}$ \\
\hline \multirow{5}{*}{$\begin{array}{l}\text { Attitude } \\
\text { Score }\end{array}$} & I strongly disagree & 23 & 3.571 & 1.006 & \multirow{5}{*}{3.597} & \multirow{5}{*}{0.007} & \multirow{5}{*}{$\begin{array}{l}\text { Absolutely I } \\
\text { agree- I strongly } \\
\text { disagree }\end{array}$} \\
\hline & I do not agree & 35 & 3.109 & 0.904 & & & \\
\hline & I am indecisive & 86 & 3.635 & 0.623 & & & \\
\hline & I agree & 51 & 3.641 & 0.566 & & & \\
\hline & Absolutely I agree & 53 & 3.627 & 0.857 & & & \\
\hline
\end{tabular}

In determining the direction of the difference, Turkey Test was used and 0.531 negative significance was found between Absolutely agree or not. 


\subsection{Information and Comments on the Relationship Between Attitude towards Vaccine and Level of Knowledge}

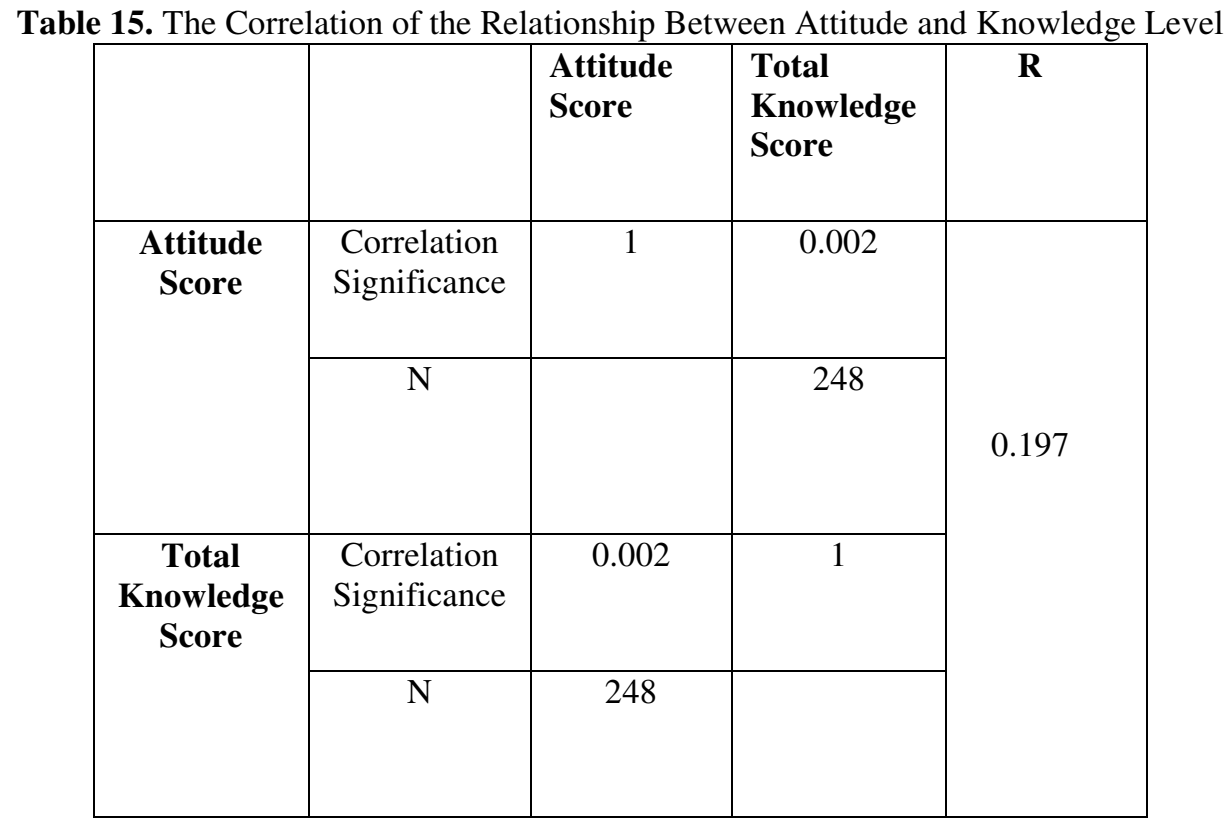

The relationship between the participants' attitude scores towards the vaccine (Mean $=3.554$, $\mathrm{SD}=0.768$ ) and the total knowledge score (Mean $=8.290, \mathrm{SD}=2.279$ ) was measured by Pearson correlation. A low level, a positive significant relationship was found between these variables. $(\mathrm{R}(246)=, 197, \mathrm{p}<0.01)$

\subsection{Investigation of the Effect of Using TV and Social Media to Access Information with Ordinal Logistic Regression on the Thought of Vaccination}

In this analysis, the use of TV and social media, which are independent variables, is evaluated categorically. The idea of vaccination, which is the dependent variable, is expressed with a sequential increasing scale. Therefore, Ordinal Logistic Regression use was deemed appropriate. The research aims to measure the effect of people who use TV and Social Media resources to obtain information on the idea of vaccination. This measurement was based on the odds (OR) ratio. Odds, the probability of observing any event; is the ratio of the probability of not being observed [34]. SPPS does not provide Odds output for the data analyzed in version 22. For this reason, the output table is transferred to Microsoft Excel and $\operatorname{Exp}\left(\beta_{k}\right)$ It was calculated according to the formula. Ordered Logistics Analysis also contains some assumptions.

When the analysis is done in SPSS package program, the results are as follows: 
Table 16. Frequencies of Data

\begin{tabular}{|l|l|c|c|}
\hline \multicolumn{2}{|c|}{} & N & $\begin{array}{c}\text { Cumulative } \\
\text { percent (\%) }\end{array}$ \\
\hline \multirow{2}{*}{$\begin{array}{l}\text { Are you considering getting } \\
\text { the Covid 19 vaccine? }\end{array}$} & "NO" & 57 & 23.0 \\
\cline { 2 - 4 } & "i am indecisive" & 79 & 31.9 \\
\cline { 2 - 4 } & "YES" & 112 & 45.2 \\
\hline \multirow{2}{*}{ TV } & 0 & 72 & 29.0 \\
\cline { 2 - 4 } & 1.0 & 176 & 71.0 \\
\hline Social Media & 0 & 67 & 27.0 \\
\cline { 2 - 4 } & 1.0 & 181 & 73.0 \\
\hline Valid & 248 & 100.0 \\
\hline Missing & 0 & \\
\hline Total & 248 & \\
\hline
\end{tabular}

Table 17.Significance and Chi-Square Value of the Model

\begin{tabular}{|l|l|l|l|l|}
\hline Model & $\begin{array}{l}-2 \\
\text { Likelihood }\end{array}$ & $\begin{array}{l}\text { Chi Square } \\
\text { Value }\end{array}$ & Df & Sig. \\
\hline Intercept Only & 49.746 & & & \\
\hline Final & 32.504 & 17.241 & 2 & 0.000 \\
\hline
\end{tabular}

For this analysis, it can be said that there is a significant difference between the variables in which the $\mathrm{H}_{0}$ a hypothesis is rejected since the $\mathrm{p}$ value is lower than 0.05 in the general result.

Table 18. The goodness of Fit Assumption for the Model

\begin{tabular}{|l|l|l|l|}
\hline & $\begin{array}{l}\text { Chi Square } \\
\text { Value }\end{array}$ & Df & Sig. \\
\hline Pearson & 0.471 & 4 & 0.976 \\
\hline Deviance & 0.476 & 4 & 0.976 \\
\hline
\end{tabular}

When the Pearson $\mathrm{p}$ value for the goodness of fit test was examined, it was seen that it was considerably higher than 0.05 . So the $\mathrm{H}_{0}$ the hypothesis is accepted. The data are suitable for the model.

Table 19. Parallelism Test for the Model

\begin{tabular}{|l|l|l|l|l|}
\hline Model & -2 Log Likelihood & $\begin{array}{l}\text { Chi Square } \\
\text { Value }\end{array}$ & Df & Sig \\
\hline Null Hypothesis & 32.504 & & & \\
\hline General & 32.062 & 0.442 & 2 & 0.802 \\
\hline
\end{tabular}

A parallel test is examined. It is concluded that the $\mathrm{p}$ value is greater than 0.05 , that is, the assumption that the $\mathrm{H}_{0}$ a hypothesis is accepted.

Table 20. The Result of Ordinal Logistic Regression Analysis

\begin{tabular}{|c|c|c|c|c|c|c|c|}
\hline & \multirow[t]{2}{*}{ Estimate } & \multirow{2}{*}{$\begin{array}{l}\text { Std. } \\
\text { Error }\end{array}$} & \multirow[t]{2}{*}{ Wald } & \multirow[t]{2}{*}{ Df } & \multirow[t]{2}{*}{ Sig } & \\
\hline & & & & & & & OR \\
\hline \multirow[t]{2}{*}{ Threshold } & $\begin{array}{l}\text { [I do not think to be } \\
\text { vaccinated }=1.0]\end{array}$ & -1.397 & 0.187 & 55.68 & 1 & 0.000 & 0.25 \\
\hline & {$[\mathrm{I}$ am indecisive $=3.0]$} & 0.088 & 0.161 & 0.298 & 1 & 0.085 & 1.1 \\
\hline \multirow[t]{4}{*}{ Location } & {$[\mathrm{TV}=, 0]$} & -1.025 & 0.270 & 14.445 & 1 & 0.000 & 0.36 \\
\hline & {$[\mathrm{TV}=1.0]$} & $0^{\mathrm{a}}$ &. & . & 0 & 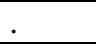 & \\
\hline & {$[$ Social Media $=, 0]$} & 0.625 & 0.281 & 4.936 & 1 & 0.026 & 1.87 \\
\hline & [Social Media=1.0] & $0^{\mathrm{a}}$ & . & . & 0 & & \\
\hline
\end{tabular}


Considering the test result, the state of thinking about getting vaccinated is the dependent variable selected as a reference, while the reference in the independent variables is the state of thinking about television as a means of obtaining information and the state of thinking about social media as an information tool. If the result is to be interpreted, the idea of being in contact with those who do not think of TV as a means of obtaining information is 0.36 times higher than those who think. ( $p<0.05, \% 95$ CI, 0.21-0.60) Those who do not think of social media as a means of obtaining information have 1.87 , or approximately two times higher, than those who think about getting vaccinated $(\mathrm{p}<0.05, \% 95 \mathrm{CI}, 1.07-3.24)$.

\section{CONCLUSIONS}

An online questionnaire was applied to 248 participants in Kocaeli province. The relationships between the participants' attitudes towards the Covid 19 Vaccine, their thoughts on getting vaccinated and their knowledge level about Covid 19 were investigated.

$43.3 \%$ of the respondents are university graduates, with $53.6 \%$ female, $46.4 \%$ male, $35.9 \%$ undergraduate and $8.5 \%$ graduate.

Skewness and kurtosis values between -1.5 and +1.5 indicate normal distribution to determine whether the data set conforms to the normal distribution. Cronbach's alpha value was found to be 0.830 .

$\mathrm{T}$ test was used for the effect of chronic discomfort on vaccination idea and there was no significant difference. The reason for this may be that those with chronic discomfort of Covid 19 fear the side effects of the vaccine. has been seen.

Pearson's chi-square analysis was conducted to examine the relationship between demographic variables and the idea of vaccination, which we determined as the dependent variable. It was concluded that the relationship between age and marital status was statistically significant. No relationship was found between education and gender and the idea of being vaccinated.

ANOVA was made for the relationship between the vaccine being indigenous and supported by WHO and the attitude and it was seen that there was a significant difference.

The difference was determined by the Turkey Test and there is a negative significance between strongly disagree and agree.

The fact that the vaccine is local is cultivated positively.

The effect of using TV and social media on the idea of vaccination was investigated to reach information with ordinal logistic regression.

Considering the test result, the state of thinking about getting vaccinated is the dependent variable selected as a reference, while the reference in the independent variables is the state of thinking about television as a means of obtaining information and the state of thinking of social media as an information tool. As a result, it has been observed that there is a significant difference between those who think of TV as a means of obtaining information and those who do not. Likewise, it was found that there is a significant difference between those who think of social media as a means of obtaining information and those who do not. 


\section{REFERENCES}

[1] World Health Organization: WHO, "Covid 19 World Statistics" Access: 15 December.2020, https://covid19.who.int/

[2] Bedford, H ve Lansley, M. (2007). More vaccines for children? Parents' views, Vaccine, 7818-7823.

[3] Marek, E., Dergez, T., Kricskovics, A., Kovacs, K., Nagy, G., Gocze, K., Kiss, I., Ember, I. and Gocze, P. (2011). Difficulties in the prevention of cervical cancer: Adults' attitudes towards HPV vaccination 3 years after introducing the vaccine in Hungary, Vaccine, 29(32): 5122-5129.

[4] Wicker,S.,Rabenau,H.,Betz,W., Lauer,H.C.,(2012). Attitudes Of Dental Healthcare Workers Towards The İnfluenza Vaccination, International Journal of Hygiene and Environmental Health, 215(4):482-486.

[5] Dany,M.,Chidiac,A.,Nassar,A., (2015). Human papillomavirus vaccination: Assessing knowledge, attitudes, and intentions of college female students in Lebanon, a developing country, Vaccine, 33(8): 1001-1007.

[6] Larson,H,Figueriedo,A.,Xiahong,Z,Schuls,W.,Verger,P,Johnston,L,Jones,N.(2016). The State of Vaccine Confidence 2016: Global Insights Through a 67-Country Survey, EBioMedicine, 295-301.

[7] Slaunwhite,J,Smith,S.,Halpferin,B.,Longley,J,Halpferin,S(2016).The Role Of Healthcare Provider Attitudes İn İncreasing Willingness To Accept Seasonal İnfluenza Vaccine Policy Changes, Vaccine, 5704-5707.

[8] Ho,H.,Chan,Y.Y,Ibrahim, M.A.,Wagle,A.,Wong,C.,Chow,A.,(2017). A Formative Research-Guided Educational İntervention To İmprove The Knowledge And Attitudes Of Seniors Towards İnfluenza And Pneumococcal Vaccinations, Vaccine, 35(47): 6367-6374.

[9] Kaya,A,Altınel,N.,Karakaya,G.,Çetinkaya,F.,(2017),.Knowledge And Attitudes Among Patients With Asthma And Parents And Physicians Towards İnfluenza Vaccination, Allergoligia et Immunopathologia, 45(3): 240-243.

[10] Lee, C., Overall, N., Sibley, C., (2020).Maternal And Paternal Confidence İn Vaccine Safety: Whose Attitudes Are Predictive Of Children's Vaccination?, Vaccine, 38(45): 7057-7062.

[11] Quinin,C,Jamioson.,A,Freimuth,V.,An,J.,Hancock,G.,Musa,D.(2017). Exploring racial influences on flu vaccine attitudes and behavior: Results of a national survey of White and African American adults, Vaccine, 1167-1174.

[12] Succi,R.(2018). Vaccine refusal - what we need to knowRecusa vacinal - o que é preciso saber, Jornal De Pediatria, 574-581.

[13] Liu,Y,Ma,C.,Jia,H,Xu,H.,Zou, Y, Zhang, Z, Hao, L. (2018). Knowledge, Attitudes, And Practices Regarding Hepatitis B Vaccination Among Hospital-Based Doctors And Nurses İn China: Results Of A Multi-Site Survey, Vaccine, 2307-2313.

[14] Lu,j,Luo,M.,Yee,A,Sheldenkar,A.,Lau,J,Liwin,M (2019). Do Superstitious Beliefs Affect İnfluenza Vaccine Uptake Through Shaping Health Beliefs?, Vaccine, 1046-1052.

[15] Jalloh,M,Jalloh,M.,Albert,A,Wolff,B.,Callis,A,Ramakrishman,A,..,Nordenstedt,H (2019). Perceptions And Acceptability Of An Experimental Ebola Vaccine Among Health Care Workers, Frontline Staff, And The General Public During The 2014-2015 Ebola Outbreak İn Sierra Leone., Vaccine, 1495-1502.

[16] Dagarege,A,Krupp,K.,Fennie,K,Srinivas,V.,Li,T,Stephens,D,Madhivanan,P (2019). An Integrative Behavior Theory Derived Model To Assess Factors Affecting HPV Vaccine Acceptance Using Structural Equation Modeling., Vaccine, 945-955

[17] Toll, M., Li, A.,(2020) Vaccine Sentiments And Under-Vaccination: Attitudes And Behaviour Around Measles, Mumps, And Rubella Vaccine (MMR) in An Australian Cohort. Vaccine Journal.

[18] Otieno, N., Nyawanda, B., Otiato, F., Adero, M., Wairimu, W., Atito, R., Wilson, A., Casanova, I., Malik, F., Verani, J., Widdowson, M., Omer, S., Chaves, S.,(2020). Knowledge And Attitudes Towards Influenza And Influenza Vaccination Among Pregnant Women in Kenya. , Vaccine, 38(43): 6832-6838. 
[19] Maltezou,H.,Theadora,M.,Lydras,T.,Fotiou,A.,Nino,E.,Theodoridou,M.,Rodolakis,A. (2020). Knowledge, Attitudes And Practices About Vaccine-Preventable Diseases And Vaccinations Of Children Among Pregnant Women In Greece., Vaccine, 38(48): 7654-7658.

[20] Carlson, S.J., Scanlan, C., Marshall, H., Blyth, C., Macartney, K., Leask, J. (2019).Attitudes About And Access To Influenza Vaccination Experienced By Parents Of Children Hospitalised For Influenza in Australia., Vaccine, 37(40): 5994-6001.

[21] Ganczack, M., Kalinowski, P., Dabrowska, M., Biesiada, D., Dubiel, P., Topczewska, K., Biesiada, A., Mazurek, D., Korzen., M. (2020).School Life And İnfluenza İmmunization: A Cross-Sectional Study On Vaccination Coverage And Influencing Determinants Among Polish Teachers., Vaccine, 35(34): 5548-5555.

[22] Francella,B,Alacreu,A.,Balzarini,F,Sigronelli,C.,Lopalko,İ,Odene,A(2020). Effectiveness Of Email-Based Reminders to Increase Vaccine Uptake: A Systematic Review., Vaccine, 433-443.

[23] Spana,M,Brunson,E.,Long,R,Ruth,A.,Ravi,S,Trotochaund,M,..,White,A.(2020). The Public's Role in COVID-19 Vaccination: Human-Centered Recommendations to Enhance Pandemic Vaccine Awareness, Access, And Acceptance in The United States. Vaccine

[24] Chan,M,Jamieson,K.,Albarcin,D.(2020). Prospective Associations Of Regional Social Media Messages With Attitudes And Actual Vaccination: A Big Data And Survey Study Of The Influenza Vaccine in The United States, Vaccine, 6236-6247.

[25] Kruse,M,Bednarczyk.,R,Evans,D.(2020). A Human Rights Approach To Understanding Provider Knowledge And Attitudes Toward The Human Papillomavirus Vaccine in São Paulo, Brazil., Papillomavirus Research, 100-197.

[26] Chan,M,Jamieson,K.,Albarcin,D.(2020).Prospective Associations Of Regional Social Media Messages With Attitudes And Actual Vaccination: A Big Data And Survey Study Of The Influenza Vaccine in The United States, Vaccine, 6236-6247.

[27] Okoli,C.,Lam,O.,Abdulwahed,T.,Neilson,C.,Mahmud,S.,Setta,A.,(2020). Seasonal Influenza Vaccination Among Cancer Patients: A Systematic Review And Meta-Analysis Of The Determinants. , Current Problems in Cancer

[28] Lee, C., Overall, N., Sibley, C., (2020).Maternal And Paternal Confidence in Vaccine Safety: Whose Attitudes Are Predictive Of Children's Vaccination?., Vaccine, 38(45): 7057-7062.

[29] Grech, V., Gaucci, C.,(2020).Vaccine Hesitancy in The University Of Malta Faculties Of Health Sciences, Dentistry And Medicine Vis-À-Vis Influenza And Novel COVID-19 Vaccination., Early Human Development

[30] Bell, S., Clarke, R., Jack, S., Walker, J., Paterson, P.,(2020).Parents' And Guardians' Views On The Acceptability Of A Future COVID-19 Vaccine: A Multi-Methods Study in England., Vaccine, 38(49): 77897798.

[31] Cagol, L. ,Seitel, T. ,Ehrenberg, S., Frivolt, K., Krahlı, A., Lainka, E., Gerner, P., Lenhartz, H., Vermehren, J., Radke, M., Koletzko, S., Debatin, K., Mertens, T., Pozovszky, C. (2020).Vaccination Rate And Immunity Of Children And Adolescents With Inflammatory Bowel Disease Or Autoimmune Hepatitis in Germany.,Vaccine, 38(7): 1810-1817.

[32] Ward,J.,Alleaume,C..,Watel,P.P,(2020).The French Public's Attitudes To A Future COVID-19 Vaccine: The Politicization Of A Public Health Issue., Social Science \& Medicine, 265.

[33] Goldman, M., Seiler, B., Eileen, K., Shimizu (2020). Caregivers' Willingness to Accept Expedited Vaccine Research During the COVID-19 Pandemic: A Cross-Sectional Survey., Clinical Therapeutics, 2124-2133.

[34] Şenel, S., Alatlı, B. (2014) Lojistik Regresyon Analizinin Kullanıldığı Makaleler Üzerine Bir İnceleme, Ĕgitimde ve Psikolojide Ölçme ve Değerlendirme Dergisi,5(1): 35-52. 